Accepted for publication in Dublin James Joyce Journal published by James Joyce Research Centre and National Library of Ireland

\title{
“' 'The More Subtle Inquisitor:' Arthur Machen as Early Reviewer of Dubliners for Grant Richards"
}

Christine Ferguson, University of Stirling

The torturous publication history of Dubliners is now well known to Joyce scholars, having received its most extensive and nuanced explication by Clare Hutton. In her masterful account of the collection's vexed transit from Heinemann through to Grant Richards, Maunsel \& Co. and then back to Richards again, she challenges the critical mythology which positions Richards in 1906 as a cowardly, irascible or careless publisher beholden to the squeamish moral sensitivities of his printer. ${ }^{\mathrm{i}}$ The new, more complex picture she paints of Dubliners' early reception at Grant Richards and Maunsel and Co. points instead to the role of multiple actors and material factors in shaping the fate of the work. A letter in the Vodrey Collection of Arthur Machen Papers at Princeton University dramatically expands our understanding of the early Richards-Joyce negotiations even further by revealing for the first time an additional, and hitherto unacknowledged reader, of the 1906 Dubliners manuscript for Richards: the Welsh gothic writer and mystic Arthur Machen. The unlikely pairing of these two figures from seemingly opposite ends of the early twentieth-century literary spectrum - one a cosmopolitan pioneer renowned for his radical aesthetic innovation, the other a reactionary popular fiction writer best known for his Stevensonian pastiches and jingoistic ghost stories - can transform our understanding, not only of Dubliners' publication history, but of the literary affinities and networks which connected popular and vanguard artists in the early modernist era. ${ }^{\text {ii }}$

Born in Caerleon in 1863, Machen migrated to London in the early eighteeneighties to launch his literary career. After a few failed experiments in reviving eclipsed literary styles, and a brief stint as cataloguer with the occult publisher George Redway, he gained fame — or at least notoriety — with a series of sensational early- 
Accepted for publication in Dublin James Joyce Journal published by James Joyce Research Centre and National Library of Ireland

nineties horror stories, most notably The Great God Pan (1894), published in John Lane's Keynotes series. Condemned by some of its contemporary critics for its decadence and perceived obscenity— the Westminster Review dubbed it "an incoherent nightmare of sex" - the novella borrowed the fragmented narrative style of Stevenson's The Strange Case of Doctor Jekyll and Mister Hyde (1886) to describe the life of the beautiful but unspeakably evil Helen Vaughan. ${ }^{\text {iii }}$ Born out of coercive sexual union between a victimized street girl and the pagan deity Pan, she grows up to unleash a wave of suicidal destruction amongst London's aristocratic men. Although one of Machen's more commercially successful stories, The Great God Pan was by no means his favorite, and he bitterly resented the financial pressures that induced him to continue pumping out works in this vein, such as 1895's The Three Impostors, for the rest of the decade "To recook that cabbage which was already boiled to death," he laments in his 1923 autobiography Things Near and Far, was "a kind of agony."iv In 1897, he completed The Garden of Avallaunius, the ambitious semiautobiographical symbolist künstlerroman that he hoped would launch a new phase in his literary career and which many of his admirers then and since have regarded as his greatest accomplishment. ${ }^{\mathrm{v}}$ The manuscript was that year offered to and rejected by Grant Richards, who, despite his admiration for the novel, cautioned against publication lest it break with the established Machen horror brand; ${ }^{\mathrm{vi}}$ later Richards relented and published the book under its new title, The Hill of Dreams, in 1907. These experiences align Machen and Joyce in a number of compelling and unexpected ways at the fin de siècle: both were writers of Celtic origins at work on autobiographically-inspired artist novels, ambivalent about literary commercialization, and due to experience considerable setbacks in their dealings with an appreciative if financially cautious Grant Richards. 
Accepted for publication in Dublin James Joyce Journal published by James Joyce Research Centre and National Library of Ireland

Despite The Hill of Dreams's initial rejection, Machen continued to correspond and work with Richards in the first years of the twentieth century, publishing with the house his critical study of the Western romance tradition, Hieroglyphics (1902), and in 1906 a new compilation of his eighteen-nineties gothic tales, The House of Souls. Machen was somewhat cynical about the latter enterprise, only consenting to the publication in deference to the dire financial exigencies that sadly daunted his entire post-Victorian career. "My only object, you know, [in] complying with your desire re: these books and stories," he writes in an early 1906 letter to Richards, "is to get a little money. Otherwise the whole lot should have stayed in oblivion so far as I am concerned." "vii This penury may well have compelled him to take on the manuscript blurbing and reviewing work for Richards that the Vodrey collection evidences. The archive contains two letters from Machen written in response to reviewing requests from Richards. In one, Machen turns a job down, saying of the unidentified manuscript, "I am very sorry; but I cannot think of anything today about the book. I am sure you will concoct a much better paragraph than I could."viii In the other, he offers a brief but rapturous review of what he refers to as Joyce's "Irish Stories."'ix Machen's readiness to turn down vetting requests for manuscripts that did not inspire him makes his enthusiasm for Dubliners all the more significant.

The letter containing Machen's report to Richards is undated, but seems, through its reference to a recent, vituperative review of Machen's The House of Souls in the Manchester Guardian, to have been published in mid-to late July $1906{ }^{\mathrm{x}}$ This timing positions it at a particularly crucial point in Joyce's increasingly fraught negotiations with Richards. Joyce had sent the original manuscript of Dubliners, containing twelve of the collection's ultimately fifteen stories, to Richards in late November 1905; ;i $^{\text {on the }} 17$ of February 1906, Richards wrote to accept, identifying 
Accepted for publication in Dublin James Joyce Journal published by James Joyce Research Centre and National Library of Ireland

himself and some as yet unnamed others as readers, and indicating his willingness to publish even though he doubted its profitability: "I do not see that it has any of those selling qualities for which a publisher has naturally to look [...] However, I admire it so much myself, and it has been so much admired by one or two other people who have read it, that we are willing to take the risk of its publication [...]." ${ }^{\text {,xii }}$ In late April, Richards developed cold feet after his printer refused to publish the newly added "Two Gallants."xiii Over the next few months, he wrote to Joyce requesting new changes both to this and other stories before finally retracting his acceptance on September $24^{\text {th }}$, despite Joyce's concession to a number of revision requests. ${ }^{\text {xiv }}$ What version of the manuscript did Machen see, and what, if any, impact did his recommendation have on Richards's final decision in the autumn of 1906? As Machen makes no specific reference to the two stories added later in 1906, "Two Gallants" and “A Little Cloud”_ “The Dead” wasn't completed until 1907 (JJII 264) — he could have received the manuscript early in the year, a possibility further suggested by the fact that Richards identifies only Filson Young as external reader to Joyce in his letter of May $10^{\text {th }}$. Regardless of when Richards decided to enlist Machen, it is clear that his quest for the Welshman's opinion represents his caution about the manuscript and desire to enlist a diverse group of readers for this attractive but potentially risky publishing venture.

Machen's $s$ succinct but unequivocally positive response to Dubliners openly acknowledges the potentially actionable nature of its sexual references. Fascinatingly, the story that seemed to him most problematic in this respect was not either of the ones rejected by the printer- "Two Gallants" and "Counterparts" — but rather the one identified by Joyce himself as the more scandalous tale, "An Encounter." "The printer denounces Two Gallants and Counterparts," Joyce had written to Richards on 
Accepted for publication in Dublin James Joyce Journal published by James Joyce Research Centre and National Library of Ireland

May $5^{\text {th }}$, but " $[\mathrm{t}]$ he more subtle inquisitor will denounce An Encounter, the enormity of which a printer cannot see because he is, as I have said, a plain blunt man [...]"

(Letters II 134). The "enormity" to which Joyce refers, is, of course, the implied act of public masturbation performed by the "queer old josser" that the story's two schoolboy protagonists witness when they play truant from school (D 26). Machen identified the suggestion right away. In its entirety, his letter reads:

My Dearest Richards,

I have read the Irish stories with very great interest. They are undoubtedly very good, and very original, and I think the author ought to be encouraged most heartily to devote himself to literary work. It is so refreshing to read work which is utterly free from the loathsome tricks and fakes of book manufacturing, of the stale literary pastry which forms the stock-in-trade of most of our writers.

It is a pity that one of the best of the tales_- "An Encounter" is (I should think) just over the line of the printable. Many of the others, excellent as they are, would be better, perhaps, if there were a little more "story" in them. But the total impression of lower-middle-class life in Dublin that one gets from the whole book is wonderful.

I hope the "House of Souls" is doing decently. The "Manchester Guardian" man seems cross!

I shall be glad to hear what you think of the sample chapter of the possible new book which I sent in. If you decree its existence I must, I think, write first a parody of a well-known hymn-

Earth hath many a noble city

Manchester doth all excel-

I am going out of town from Monday to Saturday next.

Yours,

Arthur Machen

The new book of his own to which Machen refers here is almost definitely The Secret Glory (1922), a savage indictment of the public school system cum modern Grail story which depicts the spiritually adept schoolboy Ambrose Meyrick's entrustment with, and eventually martyrdom for, the sangreal. ${ }^{\mathrm{xv}}$ Thus, even while himself occupied with a fantastical tale about the mystical regeneration of the world through a lost mythological object, Machen was able to recognize the brilliance of Joyce's 
Accepted for publication in Dublin James Joyce Journal published by James Joyce Research Centre and National Library of Ireland

symbolic-realist meditations on the lives and psychological sufferings of Dublin's petit bourgeois.

Perhaps this appreciation was no contradiction. Despite his frequent blasts against literary realism, Machen was himself fascinated by mundane experience and its potential to evoke moments of spiritual ecstasy. ${ }^{\mathrm{xvi}}$ The latter function forms the basis of the novella that is undoubtedly his masterpiece, "A Fragment of Life." Serialized in his friend A.E. Waite's Horlick's Magazine in 1904, and then revised for inclusion in The House of Souls, it tells the story of Edward Darnell, a clerk living in Shepherd's Bush clerk who, in between shopping for stoves with his wife and negotiating servant problems, experiences epiphanic visions of an ancient, pagan landscape that lies beyond the bricks and mortar of modern London. The narrative closes with a fragment from Darnell's manuscript account of his erotic, mystical union with this fantastical Ur-space:

So I awoke from a dream of a London suburb, of daily labour, of weary, useless little things; and as my eyes were opened I saw that I was in an ancient wood, where a clear well rose from grey film and vapour beneath a misty, glimmering heat. And a form came towards me from the hidden places of the wood, and my love and I were united by the well. ${ }^{\text {xvii }}$

Machen's fictional epiphanies, although, as Nick Freeman has argued, less secular and fleeting than their counterparts in the canonical modernist works of Joyce, Mansfield, and Woolf, nonetheless share their faith in the ability of everyday urban experience to not only accommodate but also to catalyze sudden moments of intense emotional, aesthetic, and even spiritual revelation. ${ }^{\text {xviii }}$ Having only recently completed the revisions of "A Fragment of Life" when he read the Dubliners manuscript, Machen may have recognized 'Araby”'s unnamed boy protagonist or “A Painful Case"'s James Duffy as more tragic and less mystically elect versions of his own Darnell. 
Accepted for publication in Dublin James Joyce Journal published by James Joyce Research Centre and National Library of Ireland

Machen's enthusiasm for the early Dubliners can help us rethink his own frequently asserted anti-modernism. Throughout the latter half of his increasingly fraught and obscure literary career, the writer was routinely curmudgeonly in his assessment of the modernist avant garde, complaining, for example, in his 1924 essay collection Dog and Duck about,

Cubism, Vorticism, Post-Impressionism; verse that doesn't scant and doesn't rhyme. [N]ovels that make one think of stupid post-mortem or a dull dissection: this is what we have in place of Tennyson, Swinburne, Rossetti, Dickens, Thackeray, the Pre-Raphaelities, and the great illustrators of that despised age, the wood-engravers whose work has become to us miraculous. ${ }^{\text {xix }}$

Similarly, in a letter to his correspondent Munson Havers from the same year, he remarks "As to modern writers of fiction; I know very little about them. When I do read a modern novel, I often make two reflections. Firstly, 'How very clever'; secondly, 'And yet this can never last'." ${ }^{\mathrm{xx}}$ Nostalgic literary reactionary as he may in these instances position himself to be, Machen would have known at the time of writing these statements that he had himself been present at, and helped to encourage, the launch of one of the most important careers in literary modernism. Admittedly, it seems unlikely that Machen would have been as encouraging and positive about Ulysses (1922) as he was for the more narratively conventionally 1906 Dubliners; nonetheless, both Joyce texts share what was for Machen the considerable virtue of rejecting the didactic, empirical tendencies of the earnest late Victorian social novels that he had lambasted in Hieroglyphics and elsewhere.

Machen's response to Dubliners constitutes a previously unknown and highly suggestive episode in the publishing history of the short story collection which could and should elicit investigation into further affinities and identifications between these two writers in the early years of the twentieth century. Machen and Joyce, after all, shared far more than just a publisher in this period. Both writers were independently 
Accepted for publication in Dublin James Joyce Journal published by James Joyce Research Centre and National Library of Ireland

pioneering an epiphanic narrative style rooted in the short story form; both too would see their early careers shaped, and even stalled, by accusations of immorality as they tried to move beyond the constrictions of the surrounding literary marketplace in their as yet inexplicit but nonetheless potent allusions to the deviations and perversities of sexual life. ${ }^{\mathrm{xxi}}$ Above all, Machen and Joyce were linked by a mutual commitment to probing the intensity of the unseen worlds that lay beneath the surfaces of social convention and rational thought, one that marks them as fellow travellers despite their radically different conceptions of the nature of these spaces, choices of literary technique for expressing them, and positions with Europe's Anglophone literary sphere. 
Accepted for publication in Dublin James Joyce Journal published by James Joyce Research Centre and National Library of Ireland

\section{Bibliography}

Arthur Machen to Grant Richards, 17 January 1906, C0240, Letters to Grant Richards, 1905-23, Vodrey Collection of Arthur Machen Papers, Princeton University Library.

Arthur Machen to Grant Richards, n.d. [circa July 1906], C0240, Letters to Grant Richards, 1905-23, Vodrey Collection of Arthur Machen Papers, Princeton University Library

Ellman, Richard. James Joyce. Oxford: Oxford University Press, 1982.

Ellman, Richard, ed. Letters of James Joyce II. New York: The Viking Press, 1966.

Freeman, Nick. "Arthur Machen: Ecstasy and Epiphany.” Literature and Theology. 24.3 (2010): 242-55.

Gekle, William Francis. Arthur Machen: Weaver of Fantasy. Millbrook, NY: Round Table Press, 1949.

Hutton, Clare. "Chapters of Moral History: Failing to Publish Dubliners." The Papers of the Bibliographical Society of America. 97.4 (December 2003): 495-519.

Joyce, James. Dubliners, ed. Robert Scholes in consultation with Richard Ellman. New York: Viking Press, 1967.

Machen, Arthur. “The Bowmen.” London Evening News. (29 September 2014): 3.

"A Fragment of Life." The White People and Other Stories, ed. S.T. Joshi. London: Penguin, 2011.

The Great God Pan: and the Inmost Light. London: John Lane, 1894.

Hieroglyphics. London: Grant Richards, 1902.

The House of Souls. London: Grant Richards, 1906.

“The Poor Victorians.” Dog and Duck. New York: Alfred A Knopf, 1924.

Things Near and Far. London: Martin Secker, 1926.

The Three Impostors; or, The Transmutations. London: John Lane, 1895.

"New Novels." Manchester Guardian. 11 July 1906: 5.

The Philistine. The New Fiction (A Protest Against Sex Mania) and Other Papers. London: Westminster Gazette Office, 1895.

Reynolds, Aidan and William Charlton. Arthur Machen. Oxford: Caerlaen Books, 1988. 
Accepted for publication in Dublin James Joyce Journal published by James Joyce Research Centre and National Library of Ireland

Richards, Grant. Author Hunting By an Old Literary Sportsman: Memories of Years Spent Mainly in Publishing, 1897-1925. London: Hamish Hamilton, 1934.

Memories of a Misspent Youth: 1872-1896. London: William Heinemann, 1932.

Scholes, Robert. "Grant Richards to James Joyce." Studies in Bibliography. 16 (1963): $139-60$.

Starrett, Vincent. Arthur Machen: A Novelist of Ecstasy and Sin. Chicago: Walter M. Hill, 1918.

Sweetser, Wesley D. Arthur Machen. London: Arthur Machen Society, 1960.

Valentine, Mark. Arthur Machen. Bridgend: Seren, 1995.

Vechten, Carl Van. Peter Whiffle: His Life and Works. New York: Alfred A Knopf, 1927.

\section{Bibliography}

i Clare Hutton, "Chapters of Moral History: Failing to Publish Dubliners," The Papers of the Bibliographical Society of America 97, no. 4 (December 2003): 497.

ii For examples of Machen's Stevensonian style, see The Great God Pan and The Inmost Light (1894) and The Three Impostors (1895); of his patriotic World War 1 ghost stories, see "The Bowmen” (1914).

iii The Philistine, The New Fiction (A Protest Against Sex Mania) and Other Papers (London: Westminster Gazette Office, 1895): 101.

iv Arthur Machen, Things Near and Far (London: Martin Secker, 1926), 104.

v Vincent Starrett, Arthur Machen: A Novelist of Ecstasy and Sin (Chicago: Walter M. Hill, 1918): 16; Carl Van Vechten, Peter Whiffle: His Life and Works (New York: Alfred A Knopf, 1927): 194; Wesley D. Sweetser, Arthur Machen (London: Arthur Machen Society, 1960): 104; Mark Valentine, Arthur Machen (Bridgend: Seren, 1995): 69.

vi Things Near and Far, 121.

vii Arthur Machen to Grant Richards, 17 January 1906, C0240, Letters to Grant Richards, 1905-23, Vodrey Collection of Arthur Machen Papers, Princeton University Library. 
viii Arthur Machen to Grant Richards, 26 January 1907, 2040, Letters to Grant Richards, 1905-23, Vodrey Collection of Arthur Machen Papers, Princeton University Library.

At the time of writing, I have only had access to the Machen side of this correspondence; the Grant Richards archive at the University of Illinois UrbanaChampaign may indicate further evidence of these arrangements. Richards's two autobiographies, Memories of a Misspent Youth, 1872-1896 (1932) and Author Hunting by an Old Literary Sportsman: Memories of Years Spent Mainly in Publishing, 1897-1925, have almost as little to say about Machen as they do about Joyce (who is not mentioned in either); as such, it is difficult to assess from these the full extent of the two men's working relationship.

ix Arthur Machen to Grant Richards, n.d. [circa July 1906], C0240, Letters to Grant Richards, 1905-23, Vodrey Collection of Arthur Machen Papers, Princeton University Library: 1.

x “New Novels," Manchester Guardian (11 July 1906): 5.

The review critiques what it views as the arrogance of Machen's preface, negatively contrasts his work to Maeterlinck's, and accuses his fiction of cultivating physical disgust instead of the numinous mystery for which it aims.

xi Robert Scholes, “Grant Richards to James Joyce," Studies in Bibliography 16 (1963): 142.

The original Dubliners comprised "The Sisters," "An Encounter," "Araby," "The Boarding House," "After the Race," Eveline," "The Clay," "Counterparts," "A Painful Case," "Ivy Day in the Committee Room," "A Mother," and "Grace"; "Two Gallants," "A Little Cloud," and "The Dead" were yet to come.

xii Grant Richards to James Joyce, 17 February 1906, in Robert Scholes, "Grant Richards to James Joyce," Studies in Bibliography 16 (1963): 143.

xiii Hutton, "Chapters of Moral History," 499.

Attributed by Joyce to a sense of bourgeois puritanical outrage, the printer's objections may in fact, as Hutton argues, have had more to do with his fear of prosecution under the 1857 Obscene Publications Bill.

xiv Grants Richards to James Joyce, 24 September 1906, in Scholes, 151.

xv Aidan Reynolds and William Charlton, Arthur Machen (Oxford: Caermaen Books, 1988): 103.

Although started in 1907, The Secret Glory did not see print until 1922 when it was finally published by Martin Secker. 
xvi Machen's most sustained critique of realism comes in Hieroglyphics, in which he repeatedly elevates the romance tradition over the realist and identifies as "the enemy" as those "who maintain that fine literature is a faithful reflection of life, and think that Jane Austen touched the point of literary supremacy" (36).

xvii Arthur Machen, “A Fragment of Life," in The White People and Other Stories, ed. S.T. Joshi. (London: Penguin, 2011): 222.

xviii Nick Freeman, “Arthur Machen: Ecstasy and Epiphany,” Literature and Theology 24.3 (2010), 242.

xix Arthur Machen, “The Poor Victorians," Dog and Duck (New York: Alfred A Knopf, 1924), 147.

xx Arthur Machen to Munson Havers, 1924, in A Few Letters from Arthur Machen, (Cleveland: The Rowfant Club, 1932), 29.

xxi William Francis Gekle, Arthur Machen: Weaver of Fantasy (Millbrook, NY: Round Table Press, 1949), 44.

In addition to the controversy around The Great God Pan, Machen has also caused a stir with his 1890 short story "A Double Return," in which a man returns home from a painting trip in Cornwall to discover that his wife has the night before been visited by, and presumably taken to her bedroom, a lookalike rival who she took for him. The $S t$ James Gazette, original publisher of the tale, dropped Machen from their contributor list following the furor. 